\title{
Distribution of ground beetles of the genus Amara Bonelli, 1810 (Coleoptera, Carabidae) in the agrolandscape in Northwestern Russia
}

\author{
O.G. Guseva, A.G. Koval \\ All-Russian Institute of Plant Protection, Podbelskogo 3, St. Petersburg, Pushkin, 196608, Russia \\ E-mail: olgaguseva-2011@yandex.ru, agkoval@yandex.ru
}

\begin{abstract}
The article investigates the abundance of beetles of the genus Amara in the agrolandscape of the Leningrad Region. In the period from 2004 to 2010, 14 Amara species were collected by pitfall trapping. Amara fulva (O.F. Müll.) is the most common species in the potato and clean fallow fields, Amara similata (Gyll.) - in the grain and grasses fields, and $A$. communis (Pz.) - in adjacent semi-natural habitats respectively. The cluster analysis shows that assemblages of ground beetles of the genus Amara in fields of different crops, field boundaries, and adjacent habitats are separated from each other. In the agrolandscape, the population of beetles of the genus Amara reaches its greatest species richness and abundance in perennial grassfields. In addition, to our best knowledge, this research was a first time when Amara ingenua (Duft.) was observed feeding on the flowering spikelets of timothy grass (Phleum pratense L.).
\end{abstract}

Key words: biodiversity, Amara, agrolandscape, Northwestern Russia.

\section{Introduction}

The genus Amara Bonelli 1810 (Coleoptera, Carabidae) includes a large number of open-area species, they are common in the agrolandscapes. Ground beetles (carabids) of this genus are typically mixophagous, have varied diets, a significant proportion of which may be crop pests. Amara aenea (DeGeer, 1774) are clearly polyphagous, they consume pests belonging to 4 orders (Sunderland, 2002). Amara similata (Gyllenhal, 1810) are implicated as slug predators (Mollusca) (Sunderland, 2002), aphids Rhopalosiphum padi (L.) (lørgensen \& Toft, 1997) and Colorado potato beetle Leptinotarsa decemlineata Say (Koval, 1999). Amara bifrons (Gyllenhal, 1810) and Amara plebeja (Gyllenhal, 1810) consume aphids Rhopalosiphum padi (L.) (Andersen, 1992).

Many ground beetles of the genus Amara are known as granivores. Seeds are still a major part of the diet for $A$. aenea (Lindroth, 1986; Tooley \& Brust, 2002). The most favored seeds for A. aenea are Poa trivialis L. (Gramineae) (Tooley, Froud-Williams, Boatman, \& Holland, 1999). Moreover, A. aenea and A. familiaris (Duftschmid, 1812) prefer feeding on seeds less than three $\mathrm{mm}$ in length (Tooley \& Brust, 2002). The food of the adult $A$. eurynota (Panzer, 1796) also consists in part of plants, for example seeds of Capsella (Lindroth, 1986). A. plebeja (Gyllenhal, 1810) is observed feeding on flowers of Alopecurus geniculatus L. (Hůrka, 1996).

However, abundance and special composition of ground beetles of the genus Amara in the different parts of agrolandscapes still remains understudied.

This study aims to determine the structure, species richness, and abundance of the Amara population on the different fields and adjacent semi-natural habitats.

\section{Material and methods}

Our work is based on the data collected during the 2004-2010 period in the framework of a joint project with the Agrophysical Research Institute (ARI, St. Petersburg) (Guseva \& Koval, 2015; Guseva, 2018). The data was collected by pitfall trapping in experimental crop rotation systems in the Leningrad Region. The research was carried out in the potato, clean fallow, perennial grasses (clover and timothy grass), vetch-oat mixture, and grain crops fields of the Menkovo Research Station (MRS) of ARI (Menkovo Vill., Gatchina Distr., Leningrad Region) (Fig. 1). The initial soil is of the soddy subpodzolic sandy loam variety. During the whole period in MRS agrolandscape, we have collected as much as 850 specimens from the Amara genus. 

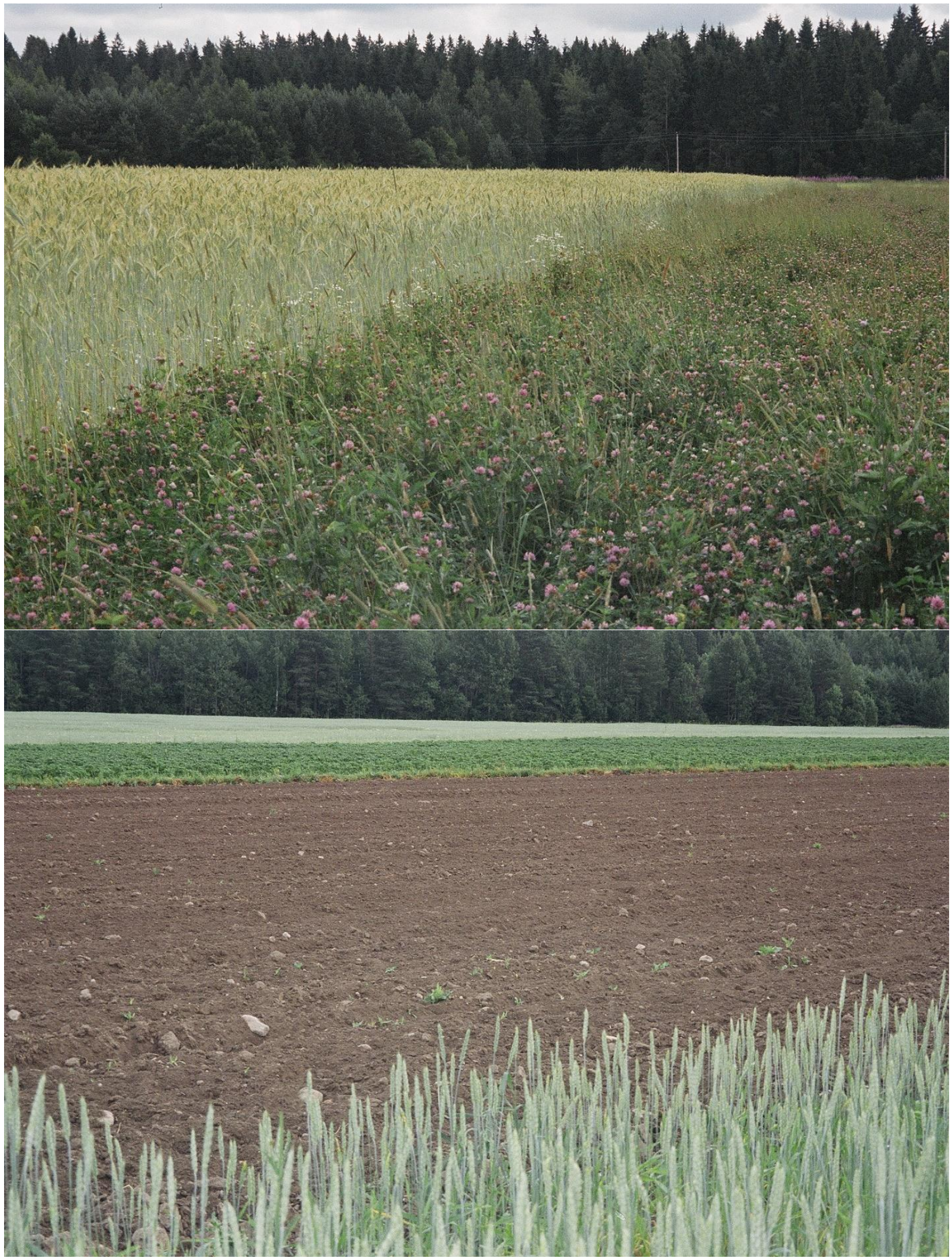

Fig. 1. The MRS agrolandscape in the Leningrad Region (perennial grasses, grain crops and fallow fields).

The species diversity of ground beetles is analyzed by standard matrices. Biotopes are listed in the rows, species are listed in the columns, and the cells contain data on the occurrence of the given species in different habitats. The matrixbased calculations are performed using the vegan package in the R software. The rarecurve function is used to analyze the species diversity of beetles in different parts of the agricultural landscape and to build rarefaction curves in order to describe the dependence of the number of species recorded on the sample size. 


\section{Results}

14 Amara species were observed in the agrolandscape in the Leningrad Region between 2004-2010. The results are presented in Table 1. Species occurrence, or catchability, is defined as the number of individuals caught per traps per 10 days (ind./10 t.d.).

Table 1. Dynamic density and special composition of ground beetles of the genus Amara in the MRS agrolandscape of the Leningrad Region

\begin{tabular}{|c|c|c|c|c|c|c|c|}
\hline Species & $\begin{array}{l}\text { Potato, } \\
2004- \\
2006\end{array}$ & $\begin{array}{l}\text { Fallow } \\
2005\end{array}$ & $\begin{array}{l}\text { Winter } \\
\text { grain, } \\
2005- \\
2006\end{array}$ & $\begin{array}{l}\text { Spring } \\
\text { grain, } \\
2005- \\
2008\end{array}$ & $\begin{array}{l}\text { Perenual } \\
\text { grasses, } \\
2004- \\
2010\end{array}$ & $\begin{array}{l}\text { Annual } \\
\text { grasses, } \\
2004- \\
2010\end{array}$ & $\begin{array}{l}\text { Field } \\
\text { boundaries,*2006- } \\
2008\end{array}$ \\
\hline A. aenea (DeGeer) & & & 0.02 & 0.01 & 0.11 & 0,07 & 0.01 \\
\hline A. aulica (Pz.) & 0.05 & 0.07 & 0.01 & 0.01 & 0.01 & 0,03 & 0.01 \\
\hline A. ingenua (Duft.) & & & & & 0.01 & & \\
\hline A. bifrons (Gyll.) & 0.05 & & 0.08 & 0.16 & 0.15 & 0.04 & 0.03 \\
\hline A. communis (Pz.) & & 0.02 & & & 0.05 & 0.01 & 0.38 \\
\hline A. consularis (Duft.) & 0.03 & 0.03 & & 0.03 & 0.04 & 0.02 & \\
\hline A. eurynota (Pz.) & & 0.03 & 0.02 & 0.05 & 0.02 & 0.01 & 0.01 \\
\hline A. famelica Zimm. & & & & & 0.01 & & 0.01 \\
\hline A. familiaris (Duft.) & 0.01 & & 0.32 & 0.03 & 0.06 & 0.02 & \\
\hline A. fulva (O.F. Müll.) & 0.23 & 0.49 & 0.02 & 0.18 & 0.15 & 0.05 & \\
\hline A. majuscula (Chd.) & 0.01 & & & 0.01 & 0.01 & & \\
\hline A. nitida (Sturm) & & & & & 0.02 & & 0.07 \\
\hline A. plebeja (Gyll.) & 0.02 & & 0.08 & 0.03 & 0.08 & 0.01 & 0.03 \\
\hline A. similata (Gyll.) & 0.02 & 0.10 & 0.45 & 0.19 & 0.30 & 0.53 & 0.02 \\
\hline No of species & 8 & 6 & 8 & 10 & 14 & 10 & 9 \\
\hline $\begin{array}{l}\text { Total catchability } \\
\text { (ind./10 t.d.) }\end{array}$ & 0.42 & 0.74 & 1.00 & 0.70 & 1.02 & 0.79 & 0.57 \\
\hline
\end{tabular}

\section{* - field boundaries and adjacent semi-natural habitats.}

Ground beetles of the genus Amara vary by their temperature, humidity, and light requirements.

A. fulva (O.F. Müller, 1776) is a xerophilous species which lives in open country on dry sand, sometimes mixed with clay (Lindroth, 1986). Therefore, $A$. fulva is the most common species in the potato fields (53 \% from the total amount of trapped individuals from the genus Amara) and fallow fields (66\%) in the MRS agrolandscape on sandy loam soil (Table 1).

A. similata in Fennoscandia lives "predominantly in open, sun-exposed country, e.g. meadows; often on arable land, notably in fallow fields" (Lindroth, 1986). A. similata in the Leningrad Region is the most common species on the annual and perennial grass and spring grain fields (Table 1).

Carl Lindroth (1986) described $A$. aenea as living "in open country on dry, sandy or clayey soil with rather dense but short vegetation". It corresponds to our results (Table 1): in the Leningrad Region the species was more numerous on the grass fields.

A. communis (Panzer, 1797) is an eurytopic species, occurring in meadows, fields, and in light forests (Lindroth, 1986). It is also common in moist, unshaded, or partly shaded, habitats: meadows, floodplain forest clearing, edges of waters, as observed in the Czech and Slovak Republics (Hürka, 1996). This corresponds to the fact that A. communis was most common species of the genus Amara in orchards in the different districts of the Leningrad Region (Guseva, Zharina, \& Zhavoronkova, 2010). In the MRS agrolandscape, $A$. communis occurred in many biotopes (Table 1), but was most numerous in the partly shaded semi-open habitats in the adjacent area (67\% from total amount of trapped Amara spp.) (Fig. 2).

A. plebeja (Gyllenhal, 1810) in Fennoscandia occurs on moderately humid soil (Lindroth, 1986). The meso-hygrophilous ground beetle species on the vetch-oat mixture fields was recorded only in the plot with a high level of soil improvement during the period of top phytomass development (Guseva \& Koval, 2015). It was more numerous on the more humid winter grain crops and perennial grass fields (Table 1).

Special composition of ground beetles of the genus Amara in the different parts of agrolandscapes depends on their specific feeding. For example, Amara ingenua (Duftschmid, 1812) in MRS agrolandscape occurs rarely: it was collected only in the perennial grass field. One strikingly interesting observation was made: it was found injuring the flowering spikelets of timothy grass - Phleum pratense L. (Gramineae) (Fig. 3). To our best knowledge, it was never mentioned in the known literature before. 


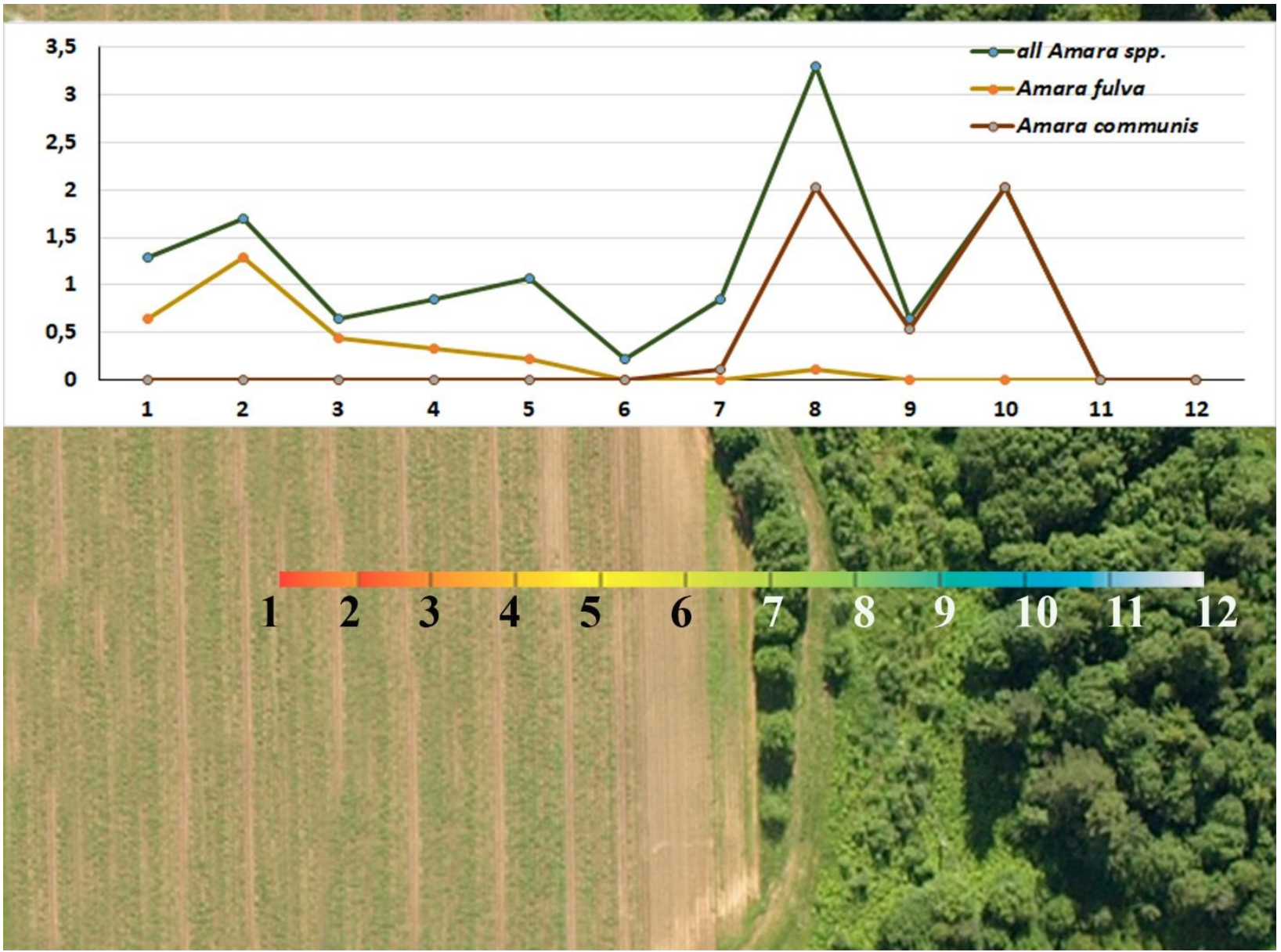

Fig. 2. Catchability of ground beetles (ind./10 t.d.) of the genus Amara in the different parts of the MRS agrolandscape. There were 12 traps, where traps 1-6 were put in the spring wheat, 7 - in the field boundaries, 8-10 - in adjacent semi-open habitats, 11-12 - on the forest edge.

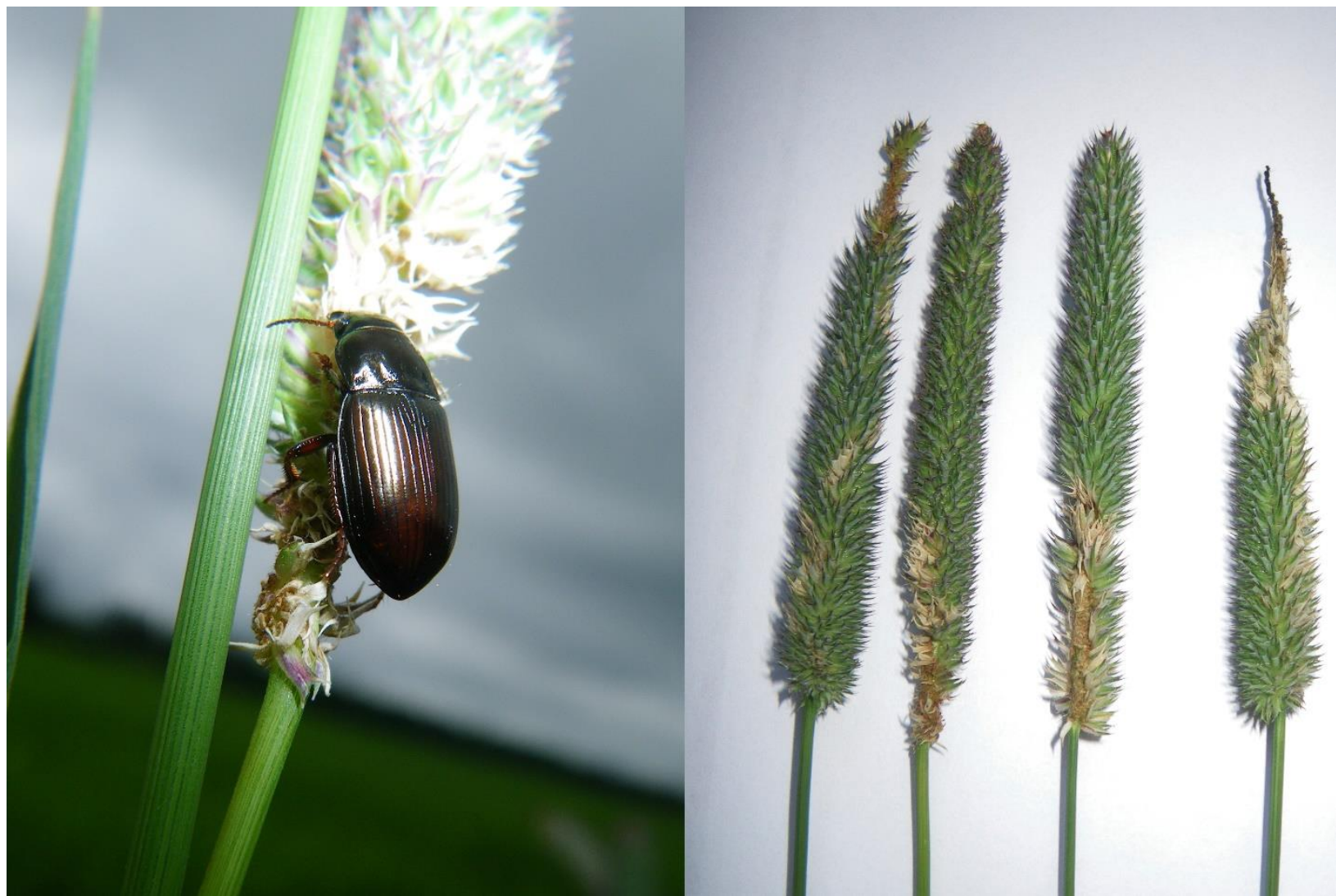

Fig. 3. Amara ingenua (Duft.) eats flowers in the spikelets of timothy grass (Phleum pratense L.) (left); the results of such damage (right). 
Assessment of the species diversity of the Amara spp. complexes using rarefaction curves shows that the assemblages from perennial grass fields (pg) have the greatest species richness while the assemblages from clean fallow ( $\mathrm{fl}$ ) have the smallest one (Fig. 4). The rarefaction curves for the Amara spp. complexes of perennial grass fields showed the greatest increase in the number of species revealed with the growing sample size (accumulated number of individuals). This implies that the number of species observed on the perennial grass fields is expected to be higher with the same sample size. For instance, with the sample size as large as 40 individuals, the predicted number of species of the perennial grass fields reaches the maximal value -10 , while reaching the lowest value of 5 on the clean fallow (Fig. 4).

All of the species of ground beetles of the Amara genus who live in the MRS agrolandscape were found only on the fields of perennial grasses (Table 1). In others habitats, the amount of registered Amara species was much smaller. Cluster analysis shows that assemblages of ground beetles of the genus Amara in fields, field boundaries, and adjacent partly shaded semi-open habitats near the forest (traps number 8-10) are different from each other (Fig. 5). Even the more striking finding was that the assemblage of ground beetles of the Amara genus on the partly shaded part of the field, where the trap 6 was placed (Guseva, 2018, p. 87, fig. 2), was similar to their assemblage on shaded field boundaries (traps 7). It demonstrates that the degree of shadow is of extreme importance for the Amara assemblages. Respectively, the abundance of beetles of the Amara genus on shadow forest edge is very low.

The similar result is obtained with the cluster analysis carried on the data on different fields (Table 1). Assemblages of ground beetles of the Amara genus in fields of different crops, field boundaries, and adjacent habitats are isolated from each other (Fig. 6). The similar assemblages were shown for the beetles of the Amara genus on the less shadowed potato fields (pt) and clean fallow (fl) (Fig. 6, table 1).

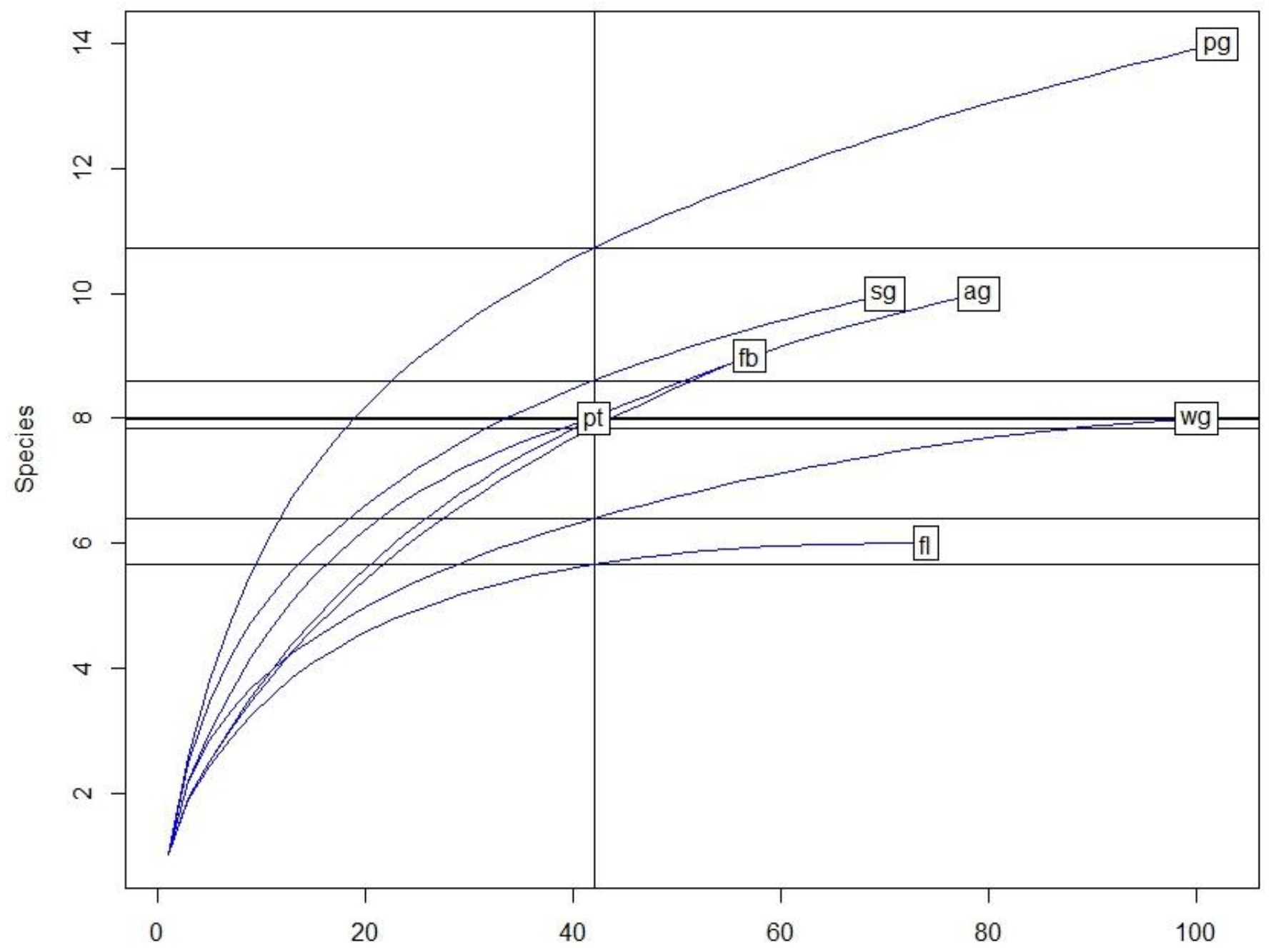

Sample Size

Fig. 4. Rarefaction curves for the Amara spp. complexes inhabiting different fields and field boundaries. Abscissa: sample size, ind.; ordinate: number of species; pt - potato fields; fl - fallow; wg - winter grain crops; sg - spring grain crops; pg - perenual grasses; ag - annual grasses (vetch-oat mixture); fb - field boundaries and adjacent semi-open habitats. 


\section{Cluster Dendrogram}

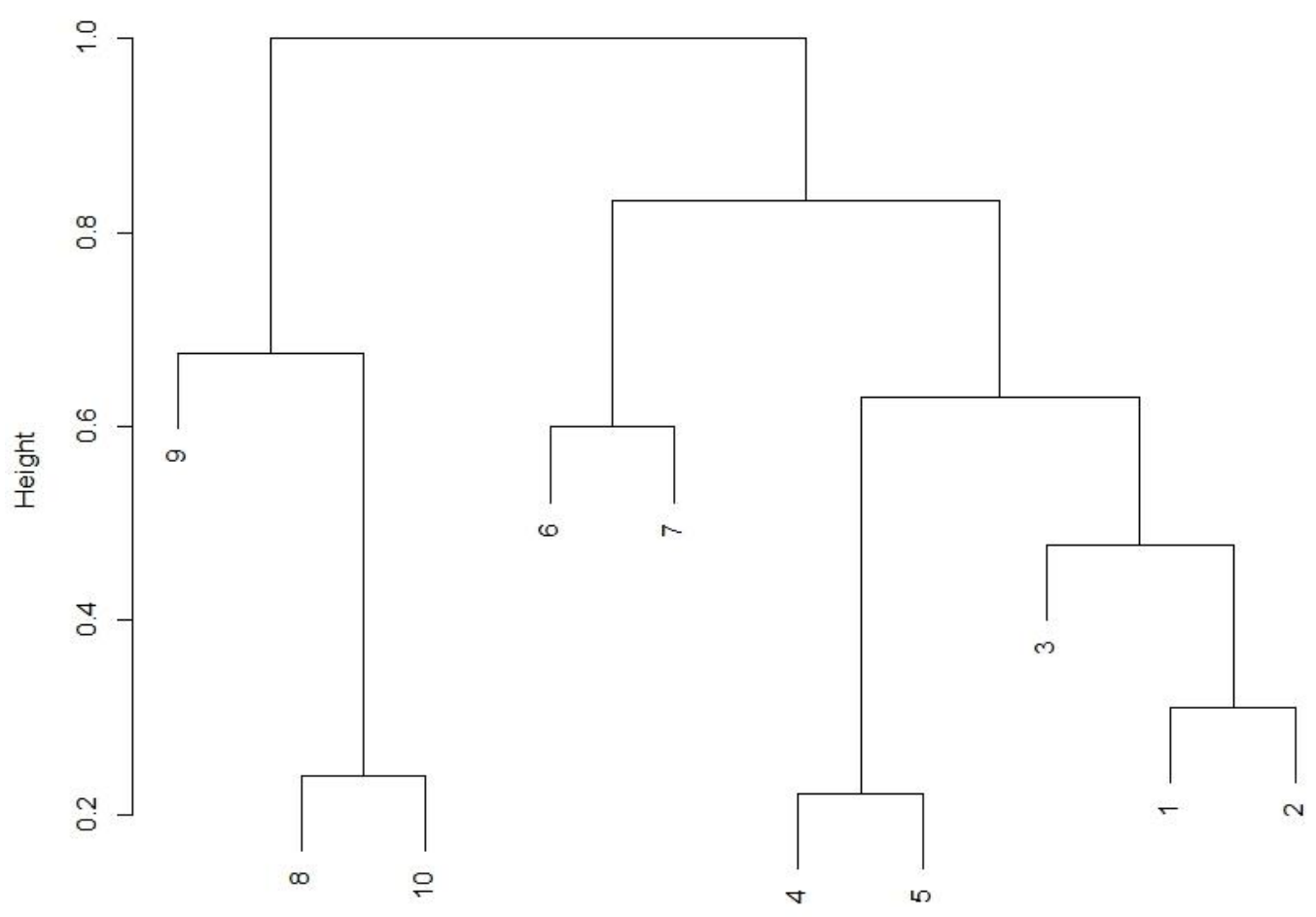

Fig. 5. Dendrogram showing the results grouping by Bray method. 1-10 -number of traps: 1-6 - spring wheat, 7 field boundaries, 8-10 - adjacent semi-open habitats.

\section{Cluster Dendrogram}

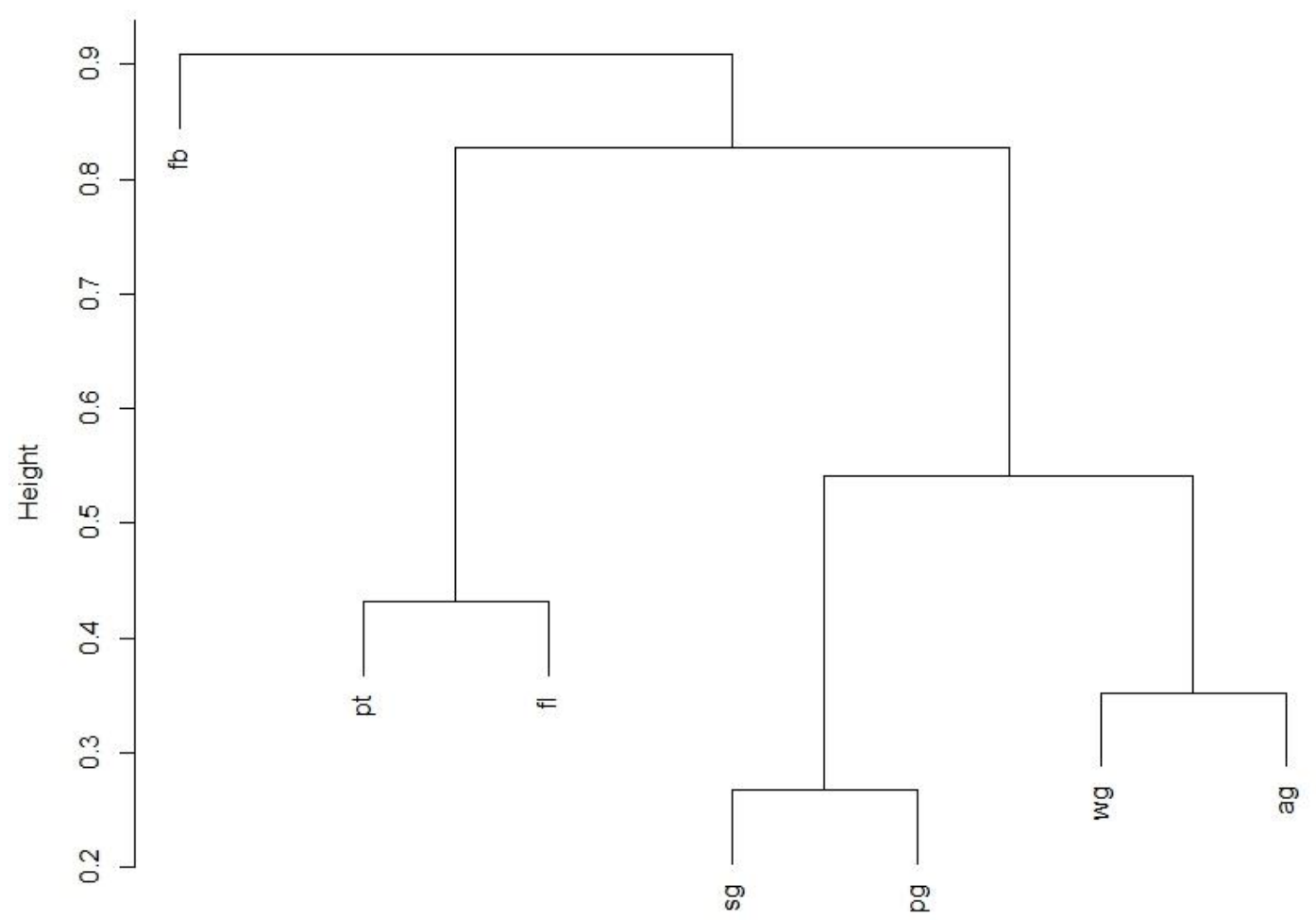

Fig. 6. Dendrogram showing the results grouping by Bray method. fb - field boundaries and adjacent semi-open habitats; pt - potato fields; fl - fallow; wg - winter grain crops; sg - spring grain crops; pg - perennial grasses; ag - annual grasses (vetch-oat mixture); fb - field boundaries and adjacent semi-open habitats. 
The investigation shows that the species composition at the landscape site appears to be determined by local crop and is connected to the temperature, humidity, and light conditions. Assemblages of ground beetles of the Amara genus in fields of different crops, field boundaries, and adjacent habitats are separated from each other. The population of beetles of the genus Amara in perennial grass fields has the greatest species richness and abundance.

\section{References}

Andersen, A. (1992). Predation by selected carabid and staphylinid species on the aphid Rhopalosiphum padi in laboratory and semifield experiments. Norwegian Journal of Agricultural Sciences, 6 (3), 265-273.

Guseva, O.G. (2018). Distribution of ground beetles of the genus Poecilus Bonelli, 1810 (Coleoptera, Carabidae) in the agrolandscape in Northwestern Russia. Acta Biologica Sibirica, 4 (3), 102-107 (in Russian). DOI: https://doi.org/10.14258/abs.v4i3.4414

Guseva, O.G., \& Koval, A.G. (2015). Influence of soddy-podzolic soil improvement on the abundance and structure of complexes of epigeic predatory beetles (Coleoptera: Carabidae, Staphylinidae) in Northwestern Russia. Entomological Review, 95 (8), 1051-1060. DOI: https://doi.org/10.1134/S0013873815080114

Guseva, O.G., Zharina, N.L., \& Zhavoronkova, T.N. (2010). Species composition and dominant structure of ground beetles and rove beetles (Coleoptera: Carabidae, Staphylinidae) in orchards of Northwestern Russia. Plant Protection News, 4, 24-31 (in Russian).

Hưrka, K. (1996). Carabidae of the Czech and Slovak Republics. Zlín: Kabourek.

Jørgensen, H.B., \& Toft S. (1997). Role of granivory and insectivory in the life cycle of the carabid beetle Amara similata. Ecological Entomology, 22 (1), 7-15. DOI: https://doi.org/10.1046/j.1365-2311.1997.00045.x

Koval, A.G. (1999). Contribution to the knowledge of carabids (Coleoptera, Carabidae) preying on Colorado potato beetle in potato fields of the Transcarpathian Region. Entomological Review, 79 (5), 523-532.

Lindroth, C.H. (1986). The Carabidae (Coleoptera) of Fennoscandia and Denmark. Leiden; Copenhagen: Scandinavian Science Press Ltd, Leiden, Copenhagen, 228-500. (Fauna Entomologica Scandinavica, 15, 2).

Sunderland, K.D. (2002). Invertebrate pest control by carabids. The agroecology of carabid beetles. Andover: Intercept, $165-214$.

Tooley, J., \& Brust, G.E. (2002). Weed seed predation by carabid beetles. The agroecology of carabid beetles. Andover: Intercept, 215-230.

Tooley, J., Froud-Williams, R.J., Boatman, N.D., \& Holland, J.M. (1999). Laboratory studies of weed seed predation by carabid beetles (1999). The BCPC conf.: Proc. of an Intl. conf. (Brighton, 1999). Farnham: British Crop Protection Council, 571-572.

\section{Citation:}

Guseva, O.G., \& Koval, A.G. (2019). Distribution of ground beetles of the genus Amara Bonelli, 1810 (Coleoptera, Carabidae) in the agrolandscape in Northwestern Russia. Acta Biologica Sibirica, 5 (1), 56-62.

Submitted: 03.12.2018. Accepted: 15.01.2019

cross ref http://dx.doi.org/10.14258/abs.

(C) 2018 by the authors. Submitted for possible open access publication under the terms and conditions of the Creative Commons Attribution (CC BY) license (http://creativecommons.org/licenses/by/4.0/). 